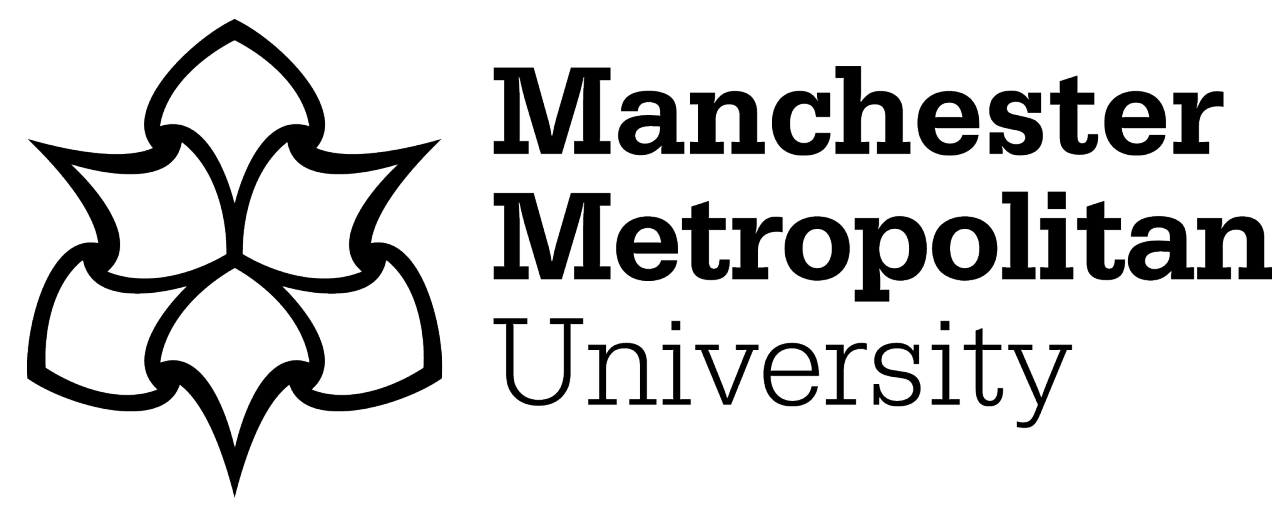

Anagnostopoulos, D, Lingard, B and Sellar, Sam ORCID logoORCID: https://orcid.org/0000-0002-2840-5021 (2016) Argumentation in Educational Policy Disputes: Competing Visions of Quality and Equity. Theory into Practice, 55 (4). pp. 342-351. ISSN 0040-5841

Downloaded from: https://e-space.mmu.ac.uk/624294/

Version: Accepted Version

Publisher: Taylor \& Francis

DOI: https://doi.org/10.1080/00405841.2016.1208071

Please cite the published version 


\section{ARGUMENTATION IN EDUCATIONAL POLICY DISPUTES: COMPETING VISIONS OF QUALITY AND EQUITY}

Dorothea Anagnostopoulos, Associate Professor of Curriculum \& Instruction Neag School of Education University of Connecticut

249 Glenbrook Road, Unit 3064

Storrs, CT 06269-3064

United States of America

Phone: 860-486-0401

Fax: 860-486-1367

Email: dorothea.anagnostopoulos@uconn.edu

Bob Lingard, Professor of Educational Policy

School of Education

The University of Queensland

Brisbane Qld 4072

Australia

Phone: +61733657343

Fax: +61 733657199

Email: r.lingard@uq.edu.au

Sam Sellar, Postdoctoral Research Fellow

School of Education

The University of Queensland

Brisbane QLD 4072

Phone: +61 733656497

Fax: +61 733657199

Email: sam.sellar@uq.edu.au 


\section{ARGUMENTATION IN EDUCATIONAL POLICY DISPUTES: COMPETING}

\section{VISIONS OF QUALITY AND EQUITY}

What is a "good" school? Who is a "good" teacher? How can we ensure that all students have access to both? Current educational policy debates revolve around these questions. How we answer them matters for whether and how we can provide a quality education for all students. In this article, we describe how policymakers and educators engage these questions as they argue about test-based accountability. Test-based accountability currently dominates educational policy and practice in the US, Australia and other industrialized nations (Van Zanten, 2008; Porter, 1995;

Lingard, 2011). It focuses entire school systems on a small set of quantitative performance indicators, most prominently standardized test scores in literacy, numeracy and sometimes science.

State, national and international policymakers use these indicators to monitor schools, teachers and students and negatively sanction those who perform below standards.

Whether the press for accountability can improve the quality of education for all students depends, in part, on the quality of our debate about such policies. The metrics and data that testbased accountability makes available provide information that might support new ways to understand and enact educational quality and equity. As they simplify and reduce complex educational processes to numerical ratings and rankings, however, these metrics can also narrow debate and the kind of education we think is possible (Anagnostopoulos, Rutledge \& Jacobsen, 2013).

In this article, we hope to help educators and other stakeholders better understand the structure of current educational policy debates and engage more deliberatively in them. We first draw on pragmatic sociology to describe the argumentation frameworks that people employ in public disputes about evaluation policies. We then explore how various stakeholders use these 
frameworks to argue about two prominent test-based accountability policies, the Organization for Economic Co-operation and Development's (OECD) Program for International Student Assessment (PISA) and enhanced teacher evaluation.

\section{Argumentation in Public Disputes}

Pragmatic sociology examines the arguments people employ to justify or critique evaluative policies that raise questions about the quality of schools and teachers. As people engage in disputes about these policies, they evoke different "orders of worth," or higher order principles, to build arguments about the policies' legitimacy and fairness. We have found Boltanski and Thevenot's (1999) work helpful in understanding these arguments. Boltanski and Thevenot (1999) identify orders of worth commonly employed in public disputes about evaluative policies: civic,

market, industrial, domestic, inspired, and fame. Each emphasizes a distinct mode of worth, test of worthiness, type of evidence, and valued human qualifications or qualities. Table 1 summarizes the orders of worth.

\section{INSERT TABLE ONE HERE}

Orders of worth are argumentation kits (Jacquemain, 2008). They provide the grammars for justifying and critiquing policies about school and teacher quality and how it should be evaluated. We highlight the industrial and civic orders here as we have found them to dominate current policy disputes about test-based accountability policies. The industrial order values technical efficiency. Industrial arguments define school and teacher quality as technical effectiveness. Tests of worth assess teachers' competence and reliability. Evidence considered valid must be measurable and includes data and statistics that compare school and teacher performance to standardized metrics. The civic order, in contrast, values the collective over individual welfare and emphasizes law, rights, and issues of equity. Tests of worth assess equality 
and solidarity. Quality schools and teachers therefore adhere to official rules and laws and seek to serve the collective good.

In modern democracies, orders of worth co-exist. Individuals and groups who mobilize multiple orders of worth garner legitimacy for their arguments and their actions (Jagd, 2011). The extent to which policymakers and educators, in particular, can balance multiple orders of worth in disputes about test-based accountability matters for their ability to withstand public scrutiny, not only of their arguments about these policies, but also of their work and their authority over it (Patriotta, Gond \& Schultz, 2011). In the following, we describe arguments surrounding the PISA and enhanced teacher evaluation, attending to the orders of worth various stakeholders mobilize and how they grapple with questions of educational quality and equity.

\section{Justifying PISA}

Promoters of the PISA primarily evoke industrial and market orders to justify international assessments as valid tests of the worth of national educational systems. As we show, this argument rests on correlating quality and equity and on re-articulating the latter into the logic of testing. International large scale assessments can be traced back to the late 1950s and the attempt, by academics, to measure educational outcomes across national systems. This history culminated in the creation of TIMSS and PIRLS by the International Association for the Evaluation of Educational Achievement, PISA by the OECD (first administered in 2000), and other lesser known assessments. Due to its policy focus and the involvement of many powerful industrialized nations, PISA is the most influential of these assessments. It tests 15 year olds on measures of reading, numerical and scientific literacies and extends beyond the 34 OECD members. Sixty-five nations participated in 2012, and more again in 2015. Every three years, newspapers around the world carry headlines describing the comparative success or failure of national education systems on 
PISA. The OECD assiduously choreographs this global media release of PISA results, enabling national media to create global league tables of national system performance. The extensive global media coverage has produced 'PISA shocks' (e.g. Germany 2001, Japan, 2006) where PISA results contradict national expectations and educational performance is framed as of national importance (Martens \& Niemans, 2013).

The graph in Figure 1 is one of the most common visualizations of PISA data. Quality, represented on the $\mathrm{Y}$ axis, is the average performance on that portion of the focal test of each round, e.g., reading, math or science. Equity, represented on the $\mathrm{X}$ axis, is the extent to which social background correlates with this performance (e.g. weaker correlation equals greater equity).

\section{INSERT FIGURE 1 HERE}

As the graph suggests, the OECD (2007) argues that quality and equity are complementary. However in its choreographed release of PISA performance data, the OECD emphasizes league tables of national performance on the quality measure. These tables get an enormous amount of media coverage, focusing debate on the achievement measure. The OECD does release a very extensive report on equity and PISA. It does so, however, quite some time after the initial release of PISA 'results' and with much less fanfare. The equity data do not get the extensive media coverage that the quality indicators garner. In its education work, the OECD also prioritizes policies that address organizational factors while eschewing consideration of structural inequalities.

While PISA allows for considerations of equity, it thus rearticulates them within the industrial and market orders of worth. Equity measures fundamentally draw on the civic order with its emphases on rights, equality and the collective good. Yet, the OECD's emphasis on achievement measures in its reports and release of PISA data gives preeminence to the industrial 
order with its focus on standardized measures of performance and productivity. As an intergovernmental organization concerned with economic policy, the OECD also argues that equity matters because of its benefits to national and global economies, illustrated by its 2012 report, "Investing in Equity in Education Pays Off" (Lingard, Sellar, \& Savage, 2014). The worth of national educational systems is determined by how well their students' performance on the relevant standardized achievement tests ranks against the performance of other nations' students. This performance matters as it contributes to a nation's human capital. Broader and more fulsome constructions of equity as equal opportunity and social equality in respect to schooling policy and practices are elided or recast according to their relation to productivity and efficiency.

The re-articulation of equity into the logic of testing exemplifies how data furnish the basis for argumentation in policy development, serving a rhetorical function and demanding debate about whether such data actually do constitute evidence. OECD reports mobilize PISA data rhetorically to argue for increasing equity and democracy, while simultaneously framing the data within the industrial and market orders. The focus on improving achievement scores will, OECD reports suggest, increase the quality and quantity of "human capital" within a given nation and thus enhance "economic productivity" and "international competitiveness" (Lingard, Sellar, \& Savage, 2014). Equity and social inclusion are valued as contributing factors in enhancing economic productivity and efficiency.

If we wish to argue with or against PISA data for equity and the democratic purposes of schooling, we must attend to the relationships between data, fact, evidence and values. Here we follow Rosenberg's (2013) useful distinction: 'facts are ontological, evidence is epistemological, data are rhetorical.... When a fact is proven false, it ceases to be a fact. False data is data nonetheless' (p.18). OECD arguments for increasing equity as a correlate to increased productivity 
and efficiency mobilizes testing as fact and evidence in relation to market and industrial values. Mobilizing counter-arguments that PISA data can also constrict our understanding of the purposes and outcomes of schooling to numbers will require evoking other orders of worth and reassessing the ontological and epistemological status of data according to their justificatory frameworks. For example, test data may provide a useful basis for factual claims about the relationship between test performance and productivity, but their status as facts may be challenged by questions of testing bias that evoke the civic order. Similarly, arguments that challenge the use of PISA data as evidence that narrowly focuses educational policy on academic literacies could be launched from the civic, domestic or inspired orders which value education for citizenship, social cohesion, and creativity, respectively.

\section{Arguing about Enhanced Teacher Evaluation}

In this section, we examine the debate surrounding enhanced teacher evaluation policies in the US, focusing on Washington DC Public School's (DCPS) IMPACT policy. If PISA represents the global reach of test-based accountability, IMPACT represents its reach into schools' core teaching and learning. Adopted in 2009, IMPACT quickly became a national model. IMPACT is a system of metrics, classifications, and compensation structures. It categorizes teachers into different groups (1 through 4), based on availability of student testing data, subjects taught, and specialization areas. Teachers in each group are rated according to their students' achievement and their instructional expertise, community contributions and professionalism. Most general education classroom teachers fall into Groups 1 and 2. In 2014-2015, ratings for teachers in Group 1 comprised 35\% value-added measures of individual teachers' contributions to their students' scores on standardized mathematics and reading achievement tests (IVA) and $15 \%$ teacherassessed student achievement data (TAS); $40 \%$ instructional expertise measured by teachers' 
average scores on multiple classroom observations conducted by school principals and districtappointed evaluators using the district's Teaching and Learning Framework rubric (TLF); 10\% Commitment to the School Community (CSC). Group 1 constitutes roughly 15\% of DCPS teachers. In 2014-2015, Group 2 teachers' ratings comprised: 75\% TLF; 15\% TAS, and 10\% CSC. Group 2 includes approximately 65\% of DCPS teachers. For all groups, Core Professionalism is determined by attendance, adherence to policies and procedures, and respectfulness. The district ties teachers' composite ratings to its performance-pay compensation system, IMPACTplus, and career ladder, LIFT. Teachers rated "ineffective" can be fired. Those rated "highly effective" can earn significant annual bonuses and salary increases, depending on their LIFT classification (DCPS, 2014a, 2014b).

Though monetary rewards evoke the market order, IMPACT rests on industrial principles, methods and evidentiary practices. It determines teachers' worth based on their productivity and competence; teachers who produce the highest gains in test scores and whose practice most closely aligns with district standards receive the highest ratings. IMPACT uses an array of statistical models and standardized tools and processes to collect evidence of teachers' effectiveness. The differentiation of teachers into IMPACT performance categories and LIFT expertise categories further exemplifies the industrial order's use of elaborate classification schemes to rank teachers' worth against their peers'.

Justifying IMPACT

Not surprisingly, proponents overwhelmingly employ industrial arguments that marshal various statistics to defend IMPACT's implementation and effectiveness. District officials justify IMPACT by repeatedly citing the discrepancy between low student achievement scores $(12 \%$ of $8^{\text {th }}$ graders at proficiency on national test) and high teacher evaluation ratings ( $98 \%$ teachers rated 
satisfactory) documented prior to IMPACT (e.g., DCPS, 2014; Education Trust \& TNTP, 2014).

DPCS officials and other proponents also frequently cite statistics from research on IMPACT's effects on teacher attrition and performance (e.g., DCPS, 2013; TNTP, 2013). The widespread circulation of these numbers reflects and strengthens their rhetorical force. The district's reports of teacher firings at the end of the policy's first year are illustrative. In 2010, the district reported that it fired 241 "ineffective" teachers (Turque, 2010a). Though it was later revealed that only 75 of these teachers had been dismissed because of "ineffective" IMPACT ratings (Turque, 2010b), the original number had garnered considerable press and been repeated in feature stories, blogs and editorials in local and national news media and electronic forums (e.g., Holland, 2010; DeVore $\&$ Cheers, 2010). The corrected number received little media coverage. While the number " 241 " had lost its ontological status as "fact," it retained its historical status as "data" in the public debate, highlighting the rhetorical force of industrial arguments in disputes about test-based accountability.

Importantly, proponents also mobilize civic arguments to justify IMPACT. ThenChancellor Rhee, for example, heralded the 241 teacher firings as fulfilling the "rights" of DCPS children, "Every child in a District of Columbia public school has a right to a highly effective teacher... Today...we take another step toward making that commitment a reality" (Turque, 2010a). In the 2009-2010 IMPACT guidebooks, Rhee similarly wrote: ...we are motivated by a commitment to ensure that the gap in achievement that separates District of Columbia children by race, class, language of origin, and special education status is eliminated once and for all. Research and experience tell us that the most important factor impacting our ability to close the achievement gap and increase student learning is you: the adults who serve our students each and every day. Recognizing the 
unparalleled importance of ensuring that talented and committed individuals are serving our students, we have developed IMPACT, the new DCPS effectiveness assessment system for school-based personnel (DCPS, 2009, p. 3).

The statement positions IMPACT as the primary means for achieving equality as defined by the elimination of various achievement gaps. While the Chancellor acknowledges teachers' potential contribution to closing these gaps, a collective goal, she emphasizes the "effectiveness" of "individual" teachers, not their collective action. Similar to PISA arguments, pro-IMPACT arguments rearticulate civic values of equity and collective action as individual teachers' efficiency measured by student achievement tests.

Critiquing IMPACT

Critics use different orders of worth to critique IMPACT. Researchers typically employ industrial arguments to question the district's calculation of value-added measures and mechanistic implementation of classroom observations (e.g. Pallas, 2010; Curtis, 2011). These critiques aim to improve the policy not challenge its conception of quality. Teachers critique IMPACT implementation with civic arguments that question its fairness. In blogs and editorials in DC newspapers, teachers denounce the district's differential use of IVA and TLF scores among DCPS teachers as "inequitable expectations" (e.g., Perschke, 2011). They also highlight the disparity between the high percentage (40\%) of teachers rated "highly effective" in the district's few lowpoverty schools versus the low percentage $(15 \%)$ of teachers rated 'highly effective' in highpoverty schools (e,g., Cintron, 2014). Importantly, though the vast majority of DCPS students live in poverty, teachers' civic critiques do not extend to broader questions of socio-economic inequality. Their arguments narrowly define equity as fairness for teachers. 
Teachers also critique IMPACT using domestic arguments. These arguments often appear in "open letters" to the DCPS Chancellor written by teachers and circulated by bloggers and newspaper columnists (e.g., Perschke, 2011; Fuchs, 2011). In these letters, teachers contest the TLF ratings assigned by district-appointed Master Educators (MEs). Teachers denounce the ME ratings, based on one hour of observations per year per teacher, as incapable of capturing the complexity of their work and their relationships with students. Teachers enumerate the extra hours they devote to teaching and school-wide duties and document their pastoral care of students as evidence of their worth. As one teacher argues, the ME ratings fail to capture the value of her work as "a mother, best friend, sister, guidance counselor, mentor and teacher" to her students (abcde, 2011). Teachers' domestic critiques thus counter IMPACT's definition of quality teaching as "effectiveness" by defining quality teaching as familial-caring whose quality is evidenced not by numerical ratings derived from systematic observations, but by personal anecdotes.

\section{Implications and Conclusion}

As our research suggests, current debate about test-based accountability is dominated by industrial arguments. This partly reflects the rhetorical force of the measures and metrics of testbased accountability. These measures radically simplify and reduce complex processes of teaching, learning and schooling into numbers, ratings and leagues tables that can circulate across local, national and international contexts and media. Even when shown to be false, these numbers profoundly shape educational policy debate, defining both quality and equity as efficiency and productivity as evidenced primarily by standardized test scores. Concerns about broader structures and impacts of poverty and social exclusion on students' lives, life chances, and educational attainment go largely unmentioned. 
If debate about test-based accountability is to support a more expansive vision of equitable education, critiques of these policies must evoke principles of the common good that extend beyond teaching and schooling and that connect to the well-being and rights of students. Such critiques will require arguing with numbers. Numbers and statistics make visible inequities in educational opportunities and in the social and economic conditions that profoundly interact with them. As Piketty in his analysis of growing levels of inequality suggests, 'Refusing to deal with numbers rarely serves the interests of the least well-off' (2014, p. 577). Arguments that seek to counter the narrow vision of test-based accountability need to rearticulate these numbers through civic arguments which emphasize collective responsibility for educational equity that extends beyond teachers and schools to include policymakers and those stakeholders with access to resources and power. While educators must counter policies that are unfair to them, they must also mobilize broader principles of the common good to garner legitimacy for their arguments and their work.

Arguing for a more expansive vision of educational quality and equity will also require finding new genres and media outlets. Proponents of test-based accountability use metrics and numbers to justify and legitimate these policies. Critics of test-based accountability more often rely on personal anecdotes of their work, relationships with students, and dispositions. Such evidence cannot be easily verified or circulated beyond local classroom and school contexts. Efforts to oppose or improve test-based accountability will depend partly, however, on marshalling this evidence in ways that enable both. This includes developing relationships with journalists, reporters and activists who can circulate this evidence. Notably, local media and bloggers in Washington D.C. did take up teachers' "open letters to the Chancellor," illustrating the rhetorical potential of the evidence and these relationships. 
At a moment in which more narrowly defined tests of school, teacher and students' worth proliferate, educators and proponents of democratic education must find ways to rearticulate ideas of effectiveness and achievement as access for all students to competent and caring teachers and to learning opportunities that engage students' academic, moral, and civic capacities and imaginations. In the end, we argue for creating and valuing "heterarchies of worth" (Lamont, 2012), or the co-existence of multiple conceptions of good teaching and good schools and of multiple ways to assess them. Establishing such heterarchies will require creating new ways of documenting and arguing for such diverse conceptions. It will also mean that public disputes about educational policy will never be fully resolved as each order of worth contains conflicting justificatory principles. Such disputes when engaged in by the widest range of stakeholders are, however, essential to democratic society and to achieving "good" and "just" schools. 


\section{References}

abcde. (2011). An open letter to the DCPS. Retrieved from http://abcde.teachforus.org/2011/04/11/an-open-letter-to-dcps/.

Anagnostopoulos, D., Rutledge, S., \& Jacobsen, R. (Eds) (2013) The Infrastructure of Accountability: Data Use and the Transformation of American Education. Cambridge, MA: Harvard Education Press.

Boltanski, L., and Thevenot, L. (1999a). On justification: Economies of worth. Princeton, NJ: Princeton University Press.

Boltanski, L. and Thevenot, L. (1999b). The sociology of critical capacity. European Journal of Social Theory, 2, $359-377$.

Cintron, A. (2014, February 19). Teacher evaluation, Part 2: In high-poverty schools, classroom observations miss the mark. Greater Education blog. Retrieved from http://greatergreatereducation.org/post/21758/teacher-evaluations-part-2-in-high-povertyschools-classroom-observations-miss-the-mark/.

Curtis, R. (2011). District of Columbia Public Schools: Defining instructional expectations and aligning accountability and support. Washington, DC: The Aspen Institute.

DCPS. (2009). IMPACT: The District of Columbia Public Schools effectiveness assessment system for school-based personnel, 2009-2010, Group 1. Washington, DC: Author.

DCPS. (2013). Teacher performance improved under DC's teacher evaluation system, new study finds. Washington, DC: Author. Retrieved from http://www.dcps.dc.gov.

DCPS. (2014a). IMPACT, The District of Columbia Public Schools effectiveness assessment system for school-based personnel: Grades 1-12, General education teachers with 
individual value-added student achievement data, Group 1, 2014-2015. Washington, DC: Author.

DCPS. (2014b). IMPACT, The District of Columbia Public Schools effectiveness assessment system for school-based personnel: Grades 1-12, General education teachers without individual value- added student achievement data, Group 2, 2014-2015. Washington, DC: Author.

DCPS. (2014c). Lessons learned from four years of implementation in DC Public Schools: An overview. Washington, DC: Author.

DeVore, V. and Cheers, I. (2010, July 23). D.C. schools chief Rhee fires 241 teachers using new evaluation system. The Rundown, PBS Newshour, Retrieved from http://www.pbs.org/newshour/rundown/dc-schools-chief-rhee-fires-241-teachers-usingnew-evaluation-system/

Education Trust and TNTP. (2014). Building a foundation for equitable access: Webinar with Houston Independent School District and Washington, D.C. Public Schools. Retrieved from http://edtrust.org/resource/building-a-foundation-for-equitable-access/

OECD. (2007) Education and training policy No more failures Ten Steps to equity in education. Paris, FR: Author.

OECD. (2013). PISA 2012 Results: Excellence through Equity (Volume II): Giving Every Student the Chance to Succeed, p. 27. Paris, FR: Author

Fuchs, L. (2011). A D.C. teacher's troubled experience with IMPACT. The Answer Sheet Blog. Washington Post. Retrieved from http://www.washingtonpost.com.

Holland, S. (2010, July 23). D.C. school system fires 241 teachers. CNN. Retrieved from http://www.cnn.com/2010/US/07/23/district.of.columbia.teachers.fired/ 
Jacquemain, M. (2008). Boltanski: A sociology of actions, regimes, polities, worlds and grammar. Retrieved from http://orbi.ulg.ac.be/bitstream/2268/90314/1/Boltanski's\%20moral\%20sociology\%20and \%20his\%20implicit\%20theory\%20of\%20ideology.pdf

Jagd, S. (2011). Pragmatic sociology and competing orders of worth in organizations. European Journal of Social Theory, 14, 343-359.

Lamont, M. (2012). Toward a comparative sociology of valuation and evaluation. Annual Review of Sociology, 38, 201-221.

Lingard, D. (2011). Policy as numbers: ac/counting for educational research. Australian Educational Research, 38 (5): 355-382.

Lingard, B., Sellar, S. and Savage, G. C. (2014) Re-articulating social justice as equity in schooling policy: the effects of testing and data infrastructures. British Journal of Sociology of Education. 35, 710-730.

Martens, K. and Niemann, D. (2013). When do numbers count? The differential impact of the PISA rating and ranking on educational policy in Germany and the US. German Politics. 22, 314-332. DOI: 10.1080/09644008.2013.794455.

Pallas, A. (2010, July 28). Were some D.C. teachers fired based on flawed calculations? The Answer Sheet Blog. Washington Post. Retrieved from http://www.washingtonpost.com.

Patriotta, G., Gond, J.P., and Schultz, F. (2011). Maintaining legitimacy: Controversies, orders of worth, and public justification. Journal of Management Studies, 48, $1804-1836$.

Perschke, A. (2011, August 16). D.C. teacher tells chancellor why IMPACT evaluation is unfair. The Answer Sheet Blog. Washington Post. Retrieved from http://www.washingtonpost.com 
Piketty, T. (2014) Capital in the Twenty-first century. Cambridge, MA: Belknap Press of Harvard University.

Porter, T. (1995) Trust in numbers: the pursuit of objectivity in science and public life. Princeton, NJ: Princeton University Press.

Rosenberg, D. (2013) Data before the fact. In L. Gitelman (Ed) 'Raw data' is an oxymoron. Cambridge, MA: MIT Press.

TNTP. (2013). The positive impact of IMPACT. Retrieved from http://tntp.org/blog/post/thepositive-impact-of-impact.

Tucker, M.C. (Ed) (2011) Surpassing Shanghai: an agenda for American education built on the world's leading systems. Cambridge, MA: Harvard Education Pres.

Tutucker. (2010, August 6). Post. The Answer Sheet blog. Washington Post. Retrieved from http://www.washingtonpost.com

Turque, B. (2010a, July 24). Rhee dismisses 241 teachers in the District; Union vows to challenge firings as result of new evaluations. The Washington Post, pp. 1A.

Turque, B. (2010b, September 13). Final count on fired teachers. The Washington Post, pp. 2B

Van Zanten, A. (2008) Competition and interaction between research knowledge and state knowledge in policy steering in France. In J.Ozga, T.Seddon and T.Popkewitz (Eds) Education research and policy: steering the knowledge-based economy. London: Routledge.

\section{Additional Resources for Classroom Use}

Jacobsen, R., Saultz, A. \& Snyder, J.W. (2013). Grading school report cards. Phi Delta Kappan, 95, 64-67. 
This article examines the design of school performance report cards created and disseminated by states under the No Child Left Behind law. The authors identify several ways in which current school report cards distort information on schools. They provide helpful suggestions on how school leaders and policymakers can select, present and communicate school data to avoid these distortions and promote public discussion and engagement in school policy.

\section{Levine, D. (2002). The Milwaukee platoon school battle: Lessons for activist teachers. The Urban Review, 34, 47- 69.}

This article tells the story of how 1920s Milwaukee public school teachers mobilized arguments against a business-model school reform aimed at increasing efficiency by radically restructuring schools along a "platoon" model. The article provides an interesting historical account of how teachers engaged the press and local civic organizations to promote an alternative vision of quality education that challenged and ultimately led to the defeat of the proposed reform. The article describe how these efforts can help contemporary teachers strengthen their voice in current educational policy debates.

\section{Rethinking Schools \\ www.rethinkingschool.org}

This website features journals and books written by teachers, parents and students that promote social justice teaching and learning. The publications provide both critical analyses of current 
school reform movements, including test-based accountability, and examples of how teachers can mobilize support for an alternative vision of high-quality education for all students. 
Figure 1. PISA Student Performance and Equity Table

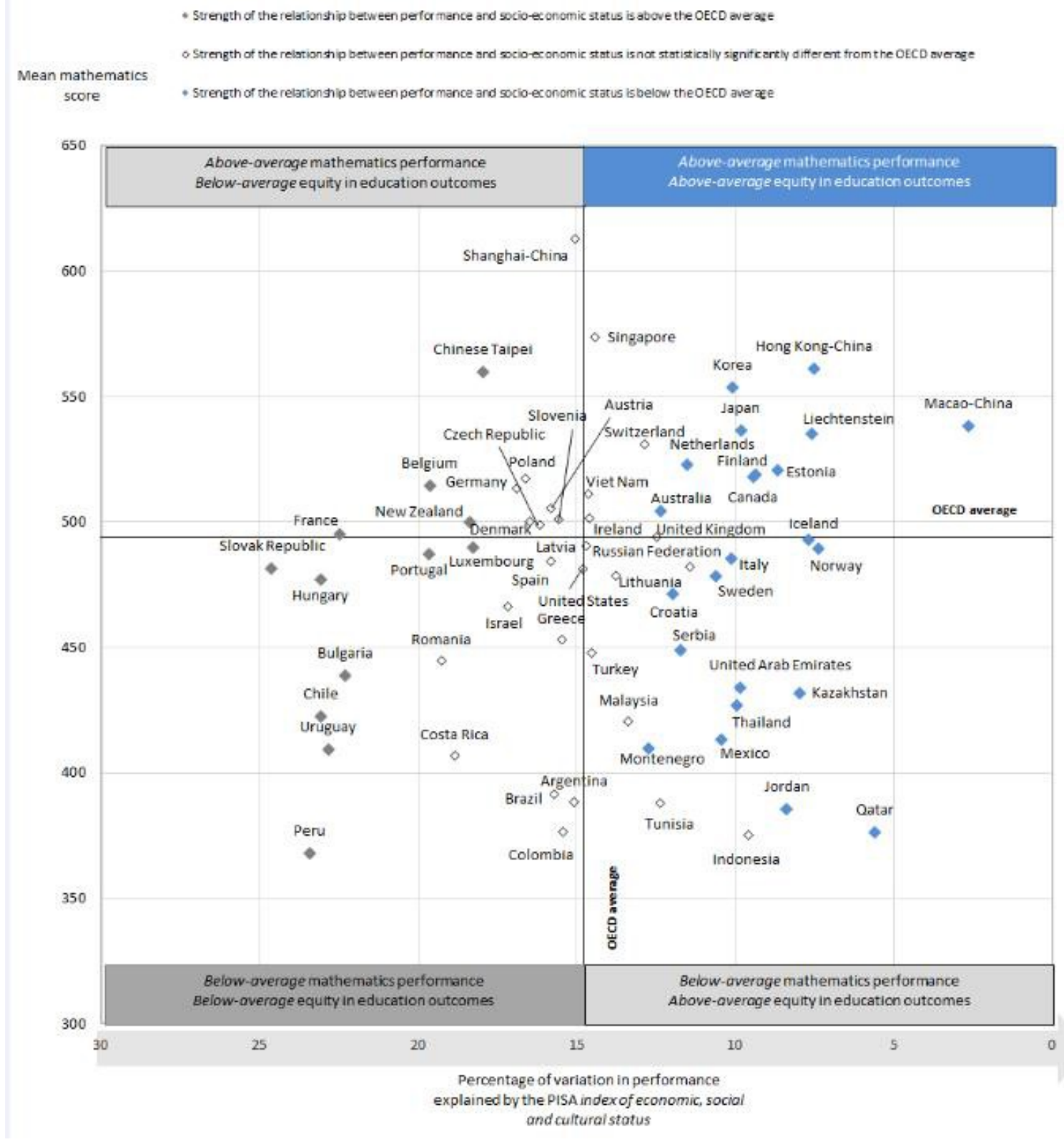

Source: OECD, 2013, p. 27 
Table 1. Orders of Worth

\begin{tabular}{|c|c|c|c|c|c|c|}
\hline Order & Industrial & Civic & Market & Domestic & Inspired & Fame \\
\hline $\begin{array}{l}\text { Basis of } \\
\text { evaluation or } \\
\text { worth }\end{array}$ & $\begin{array}{l}\text { Technical } \\
\text { efficiency }\end{array}$ & $\begin{array}{l}\text { Collective } \\
\text { welfare }\end{array}$ & Price & $\begin{array}{l}\text { Esteem, } \\
\text { reputation }\end{array}$ & $\begin{array}{l}\text { Grace, } \\
\text { creativeness, } \\
\text { nonconformity }\end{array}$ & $\begin{array}{l}\text { Renown, } \\
\text { fame }\end{array}$ \\
\hline Test & $\begin{array}{l}\text { Competence, } \\
\text { reliability }\end{array}$ & $\begin{array}{l}\text { Equality, } \\
\text { solidarity }\end{array}$ & $\begin{array}{l}\text { Market } \\
\text { Competitiveness }\end{array}$ & Trustworthiness & Passion & Popularity \\
\hline Evidence & $\begin{array}{l}\text { Measureable } \\
\text { statistics, } \\
\text { standards }\end{array}$ & $\begin{array}{l}\text { Formal } \\
\text { rules, } \\
\text { official } \\
\text { regulations, } \\
\text { laws, rights }\end{array}$ & Money & $\begin{array}{l}\text { Anecdote, case, } \\
\text { example, } \\
\text { personally } \\
\text { warranted }\end{array}$ & $\begin{array}{l}\text { Emotional } \\
\text { involvement } \\
\text { \& expression }\end{array}$ & Semiotic \\
\hline $\begin{array}{l}\text { Valued } \\
\text { Human } \\
\text { Qualification }\end{array}$ & $\begin{array}{l}\text { Professional } \\
\text { competency, } \\
\text { expertise }\end{array}$ & Equality & $\begin{array}{l}\text { Desire, } \\
\text { purchasing } \\
\text { power }\end{array}$ & $\begin{array}{l}\text { Authority, } \\
\text { tradition }\end{array}$ & $\begin{array}{l}\text { Creativity, } \\
\text { ingenuity }\end{array}$ & Celebrity \\
\hline
\end{tabular}

Source: Boltanski \& Thevenot, 1999b; Patriotta, et al, 2011 